\title{
9 Social Enterprise in the Netherlands
}

Between Hope and Hype

\author{
Philip Marcel Karré
}

\section{Introduction}

In the Netherlands, there is big hope, especially among politicians, social entrepreneurs and their advocates, that social enterprise (SE) will be able to help the government and other third-sector actors to tackle major societal problems, especially in cities. However, there is also a hype around social enterprise in the country; these initiatives get a lot of attention from the media, opinion leaders and policy makers, but there is as yet very limited knowledge of what is actually happening. Research is still scarce. Moreover, there is also a lot of confusion concerning social enterprises in the Netherlands. Indeed, there is no specific legal form or policy framework for these initiatives yet, though the Dutch government announced in July 2020 that it intends to establish a legal form and framework for what it calls the "social limited-liability company" (maatschappelijke $B V$, or $\mathrm{BVm}$ ). Until these intentions have been translated into action, every organisation can call itself a social enterprise, and many do, as the "social enterprise" label is seen as more modern than the older labels of "charity" or "foundation". Because of the Netherlands' long history of private initiative by non-profits in the provision of public goods and services, the Dutch third sector is notoriously fragmented and diverse, and it defies easy classifications. This is also true for social enterprises, which somehow remain ill-defined "new kids on the block"; indeed, even though one could say that the Netherlands already have a long tradition with social enterprises, they were not called that until very recently.

This text consists of three parts: in the first part, we describe the concepts linked to social enterprise and the context within which they have emerged and developed; in the second part, we map the SE sector and identify the various SE models in the Netherlands and in the third part, we analyse the relations between social enterprises and public authorities. 


\subsection{Understanding Concepts and Context}

In Dutch, social enterprises are known as "sociale ondernemingen"; social entrepreneurs, as "sociaal ondernemers"; and social entrepreneurship, as "sociaal ondernemerschap". Other terms that are also sometimes used are those of "sociale firma's" (social firms) and "sociale coöperaties" (social cooperatives). The term "maatschappelijke onderneming", or societal organisation, is also used, but it mainly applies to all organisational forms that originated in the third sector rather than in the state and market sectors. It is also important to note that the word "sociaal" has a narrower meaning in Dutch than the word "social" in English, which can better be translated as "maatschappelijk"; indeed, "sociaal" often only refers to the social domain (health care and welfare), though there are also social enterprises in other sectors.

\subsubsection{Definition and Legal Status}

As stated before, there is no specific policy framework or separate legal status for social enterprises in the Netherlands at the moment, and therefore no framework to determine which organisations are social enterprises and which are not. In most publications, the definition of social enterprise coined by the European Commission's Social Business Initiative $(\mathrm{SBI})^{1}$ is used:

A social enterprise is an operator in the social economy whose main objective is to have a social impact rather than to make a profit for their owners or shareholders. It operates by providing goods and services for the market in an entrepreneurial and innovative fashion and uses its profits primarily to achieve social objectives. It is managed in an open and responsible manner and, in particular, involves employees, consumers and stakeholders affected by its commercial activities. ${ }^{2}$

Social Enterprise NL, ${ }^{3}$ an advocacy group that aims to promote social enterprise in the Netherlands, has narrowed down the SBI definition to distinguish its members from what it describes as more "traditional nonprofits" (see table 9.1), stating that social enterprises are only those organisations that are "for a minimum of $50 \%$ financially dependent on trade or other forms of value exchange that are not donations or subsidies". ${ }^{4}$

The lack of a specific policy framework or separate legal status for social enterprises in the Netherlands feeds the confusion about the term. In practice, there is a wide variety of organisations that call themselves social enterprises, and the way in which they operationalise the ingredients of the above-mentioned definition is not clear. 


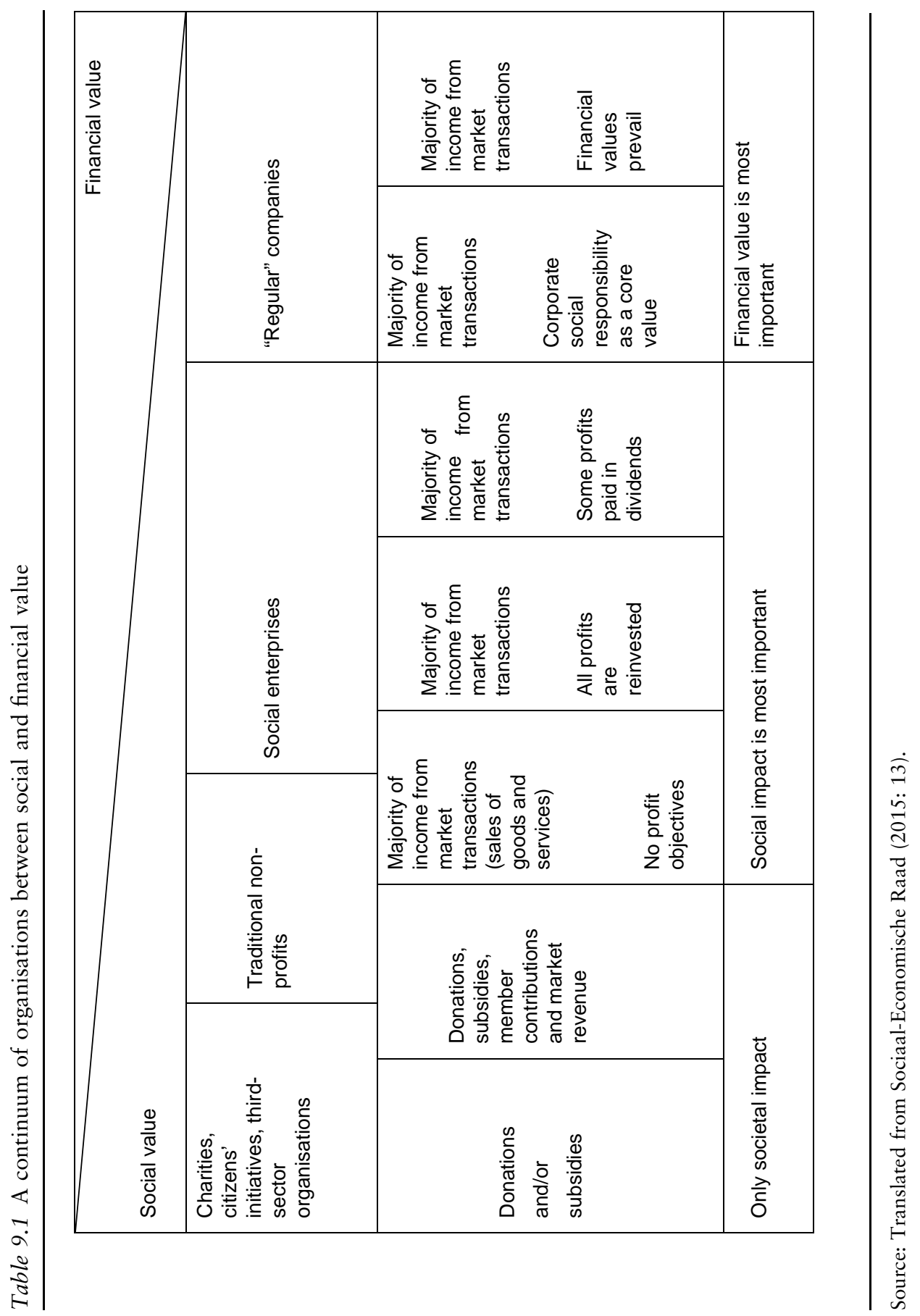




\section{Karré}

Social enterprises can operate under a wide array of legal forms. They can, as commercial enterprises, opt for the form of a private limitedliability company (besloten vennootschap, or $\mathrm{BV}$ ) or that of a public company (naamloze vennootschap, or NV). But they can just as well adopt the form of an association (vereniging), foundation (stichting) or cooperative (coöperatie). Individual social entrepreneurs often opt for the simplest legal form, that of sole proprietorship (eenmanszaak). Several social entrepreneurs can enter into a general partnership, referred to in Dutch as a "vennootschap onder firma" (VOF). These different legal forms come with different levels of requirements regarding statutes, boards, administration and finances. Only foundations are required to be not-for-profit, but that does not mean that the other legal forms cannot be used by initiatives with non-profit purposes. Private limited companies or sole proprietors are the easiest way for new organisations to get started, so the main motivation to (initially) decide on one of these legal forms may simply be because the organisation does not yet have the organisational capacity to comply with the more complex regulatory demands placed on other legal forms.

This organisational diversity is one of the reasons for the confusion and ambiguity concerning the concept of social enterprise in the Netherlands. In practice, the lack of a specific legal form or policy framework for social enterprise means that social enterprises are selfproclaimed; every organisation can label itself a social enterprise. There is a discussion about creating a special legal form for social enterprises; many social entrepreneurs are in favour of introducing such a legal form, and one of the smaller Christian parties has raised the issue in parliament. However, there are also warnings that such a move might be counterproductive, as argued, for example, in a joint report by the OECD and the EU commissioned by the Dutch government (see section 9.3 for more details).

\subsubsection{The Debate about Social Enterprise in the Netherlands}

In the Netherlands, social enterprises have been a topic of debate for some years (Brabander et al. 2009; Schulz et al. 2013; Sterk et al. 2013). The discussion mainly revolves around the role that social enterprises can play in addressing major social problems (Brandsen et al. 2016; Head and Alford 2015; Rittel and Webber 1973) at the local level, in the aftermath of the 2008 financial crisis.

This crisis made government cut-backs necessary in the provision of public goods and services. Simultaneously, Dutch municipalities became responsible for many programmes concerning public health and welfare through a major decentralisation, and they were looking for new and especially cost-effective ways to implement these programmes-an evolution that generated interest in social enterprise in Dutch society. 
Another factor that contributed to the rising interest in social enterprise is the fact that the Netherlands has a long history of private initiative, both profit- and non-profit-driven, in the provision of public services (see also section 1.3) and-also as a result of lay-offs by traditional welfare providers, due to the financial crisis-a new wave of socially engaged people with hands-on experience had become available, some of whom started their own social enterprise.

Dutch social entrepreneurs are good at making their voices heard, for example, through the advocacy group Social Enterprise NL. Moreover, due to the political developments mentioned before, social enterprises receive significant attention from the media and in policy circles-several Dutch cities have for example already adopted special action plans aimed at supporting social enterprises (see section 3). However, despite the buzz, much of the discussion about social enterprise in the Netherlands still has the characteristics of a hype, with a whole industry of workshops, roundtables and inspirational sessions springing up around the phenomenon (ABN AMRO 2017: 5). Societal expectations are high and often fuelled by canny entrepreneurs, adept at marketing their product, but the question is: What is really happening, and what effect does this have? Answering this question is important in order to separate the wheat from the chaff and to learn from really promising practices. For now, insight into how social enterprises work and which societal impact they actually generate is limited; research is only now beginning to emerge (Hogenstijn et al. 2018; Karré 2018).

\subsubsection{Historical Context}

The Netherlands has a large third sector, but also one that is "extraordinarily diverse and defies easy categorisation" (Pape and Brandsen 2016: 3). This is linked to the fact that the country has a rich tradition of provision of public goods and services by other actors than the state itself. ${ }^{5}$ Hybrid organisations that mix the institutional logics of the state, the market and civil society are the norm rather than the exception in the Netherlands in the area of provision of public goods and services. For example, many schools, universities, hospitals and housing corporations were established at the turn of the 19th century at the initiative of (groups of) socially concerned citizens and/or religious groups. Also, many of the Netherlands' public utilities (gas plants, railroads and watersupply systems) were originally established not by the state but through private initiatives of entrepreneurs, who expected a healthy return on their initial investment.

The involvement of religious and political groups in the provision of public services can also be accounted for by another reason, namely the fragmented character of Dutch society. For a long time, the Netherlands was, using the concept coined by Lijphart (1975), a "consociational" 


\section{Karré}

state (i.e., a state based on a system of power-sharing), with major internal divisions along religious and ideological lines but cooperation at the level of political and economic elites. Dutch society was divided into several so-called pillars (namely the Protestant, Catholic, Social Democratic and Liberal pillars), comprising religious as well as ideological groups that lived alongside-rather than with-each other. Each pillar had its own institutions providing public goods and services, such as schools and hospitals, based on the concept of "sphere sovereignty" (soevereniteit in eigen kring). This concept, brought forward by NeoCalvinist theologian Abraham Kuyper (who was to become prime minister later), states that each group should be allowed to deal with its own affairs without outside interference.

The rise of and discussion about social enterprise in the Netherlands must be seen against this historical backdrop, as private initiative still plays an important role in the Dutch welfare state today. At the turn of the 19th century, the state started to intervene in private initiatives, but instead of taking over these initiatives through processes of nationalisation, it rather decided to finance them. For example, we still find today confessional as well as non-confessional schools in the Netherlands, both of which are financed by taxpayers. After World War II, the Dutch government started to play a more prominent role, with the creation of a welfare state, which meant that many public-service providers became more and more dependent on the state and its financial contributions. This changed from the 1990s onwards, when budgetary constraints and a new ideological vision on the provision of public services through market mechanisms made the government rethink its role and gave rise to expectations for public-service providers to behave in a more entrepreneurial fashion. Private initiatives which, over the years, had become "encapsulated" by the state, to a point at which they were hardly distinguishable as private initiatives at all, were expected to act again more independently, to compete for government contracts and to look to the market for additional funding (Andeweg and Irwin 1993: 35-36; van Thiel 2000).

This belief in the market and the related use of new public management (NPM) as a way for the state to deal with public-service providers are now often criticised in the Netherlands as having been excessive. However, at the same time, the government lacks the capabilities and willingness to again become more active. In this general climate, there is now a renewed interest-also fed by a traditional Dutch belief in the power of private initiative-in third-sector organisations in the area of public-service provision. Some organisations in this field, but not all of them, call themselves social enterprises, but this is not a distinct or clearly defined category. Because the Netherlands has always had a large third sector, it has not been necessary to create social enterprises anew, as a third way between the state and the market. Indeed, Dutch social enterprises have always existed, even though they were not called that until recently. 


\subsection{Identification of SE Models}

In this section, we look at the various SE models in the Netherlands and how they can be classified.

\subsubsection{Mapping the SE Sector}

There are three reports that provide an insight into the development of the Dutch SE sector: a report by management consultants McKinsey (Keizer et al. 2016); another one by ABN AMRO bank (ABN AMRO 2017); and a third one by Social Enterprise NL (Social Enterprise NL 2019), an SE advocacy group.

\section{Size and Evolution of the Sector}

As there is no separate legal status for social enterprises and only a broad definition of the concept, information concerning the number of social enterprises in the Netherlands differs widely from one source to another, and data from the three reports cannot readily be compared. McKinsey, using the definition by the European Commission, estimates that there are about 5,000 to 6,000 social enterprises in the Netherlands, with a total staff of about 75,000 , and which contribute $€ 3.5$ billion to the national income (Keizer et al. 2016: 5). ABN AMRO bank uses a broader definition, encompassing every organisation with both a social dimension and an entrepreneurial one, yet only counts 4,000 to 5,000 social enterprises in the Netherlands, with a total staff of 50,000 to 70,000 employees (ABN AMRO 2017: 17).

The Social Enterprise Monitor by Social Enterprise NL includes information collected by means of a survey from 210 social enterprises (Social Enterprise NL 2019: 26). This survey is sent to the 345 members of Social Enterprise NL each year, as well as to social enterprises that are not members of Social Enterprise NL but that receive funding from Stichting DOEN, a foundation financed by three lotteries and supporting social and cultural initiatives, and to social enterprises that have relationships with the municipalities of Rotterdam, The Hague and Amsterdam. The Social Enterprise Monitor does not elaborate on how and on which grounds Stichting DOEN and the municipalities decided which organisations were to be sent the survey, nor does it provide information about the total number of social enterprises that were invited to fill in the survey.

The Dutch SE field has grown dramatically since 2010, writes McKinsey - by 2,000 to 2,500 enterprises; in other words, the sector expanded by about $70 \%$. This growth also represents about $1 \%$ of the total increase in the number of all companies in the Netherlands since 2010. Similar growth can be observed with regard to jobs and revenues: 


\section{Karré}

Since 2010, jobs in the social enterprise sector have increased by more than 60\% to 65,000-80,000 in 2016. These 25,000 new jobs come at a time when the Netherlands lost nearly 75,000 jobs in other sectors. Total revenues in the social enterprise sector rose from about 2 billion in 2010 to 3.5 billion euros in 2015, an increase of $75 \%$.

Keizer et al. (2016: 5)

\section{Areas of Activity}

According to McKinsey, Dutch social enterprises are a highly diverse group, active in a broad range of industries (Keizer et al. 2016: 9). The most important field of activity is that of "health and welfare"; $31 \%$ of social enterprises operate in this industry. It is followed by "energy" $(17 \%)$ and "financial and business services" $(16 \%)$. Also worth noting is the fact that more than $41 \%$ of social enterprises are active in two or more industries.

According to the Social Enterprise Monitor, nearly half of all the 210 social enterprises that responded to the survey see it as their mission to increase the participation of vulnerable groups (the long-term unemployed or people with a disability) in the labour market. Forty-eight percent of respondents cite this as their primary mission and $23 \%$, as their secondary mission. Other activities mentioned are: circular and sustainable production (cited by $17 \%$ of enterprises as their primary mission and by $26 \%$, as their secondary mission); the transition of food production and/or nature preservation $(8 \%$ as primary mission, $10 \%$ as secondary mission); international development and developing fair supply chains ( $9 \%$ as primary mission, $7 \%$ as secondary mission); working on increasing social cohesion in disadvantaged neighbourhoods ( $8 \%$ as primary mission, $24 \%$ as secondary mission), improving health care $(6 \%$ as primary mission, $8 \%$ as secondary mission); and accelerating the Netherlands' energy transition towards a zero-carbon economy ( $4 \%$ as primary mission, $2 \%$ as secondary mission).

\section{Size and Legal Form of the Initiatives}

With regard to the size of social enterprises in the Netherlands, ABN AMRO examined the sample of social enterprises supported by its Social Impact Fund (ABN AMRO 2017: 17). Nearly all of these could be described as small- to medium-sized companies, with a small number of employees (one or two employees in $29 \%$ of cases, and three to nine staff members in $46 \%$ of cases). These organisations were not stock-marketlisted, and most $(71 \%)$ had the form of a private limited-liability company $(\mathrm{BV})$. Less common in this database were foundations $(17 \%)$ and cooperatives $(8 \%)$. About $4 \%$ of the social enterprises listed were soleproprietor businesses, run by individuals working as social entrepreneurs 
on a freelance basis. Of course, as this subset of organisations have all had dealings with ABN AMRO Bank's Social Impact Fund, these figures are not representative of the whole SE sector.

Out of the 210 social enterprises that provided data for the Social Enterprise Monitor, $42 \%$ had a staff of 0 to 5 full-time equivalents (FTEs); $20 \%$ had 6 to $10 ; 12 \%, 11$ to $20 ; 15 \%, 21$ to 50 ; and $11 \%$, more than 50 FTEs. More than half $(52 \%)$ of the organisations in the Social Enterprise Monitor had the legal form of a private limited company (BV). Another big group was that of foundations (24\%). Less common, at least among this group of social enterprises, were organisations combining the legal form of foundation and that of cooperative $(10 \%)$, social enterprises run as sole-proprietor businesses $(4 \%)$, general partnerships (VOFs) $(4 \%)$ and cooperatives $(2 \%)$ (another group, representing $3 \%$ of respondents, indicated their legal form as "other"). Of course, since these figures are based on a survey, they are not representative of the whole SE sector either; a bias might for example result from the fact that the time needed to fill in the survey represents a comparatively larger investment for smaller organisations, thus leading to an over-representation of bigger organisations in the sample.

\section{Failure Rate}

Not all social enterprises are successful. According to McKinsey, about 700 social enterprises-roughly $20 \%$ of those that existed in 2011 - had ceased operations in 2016, mostly because their business models were unsustainable (Keizer et al. 2016: 5). ABN AMRO reports that, when updating the data in their database in 2016, they found that $15 \%-20 \%$ of social enterprises had already ceased trading since 2012 (ABN AMRO 2017: 19).

\section{Age of Entrepreneurs and Enterprises}

Most social entrepreneurs behind the social enterprises in the ABN AMRO database are between 35 and 55 years of age (61\%). Some are younger $(25 \%)$ and some are older $(14 \%)$, but none is under the age of 25 years (ABN AMRO 2017: 18). However, the fact that, on average, social entrepreneurs are middle-aged persons should not be understood as meaning that they have been social entrepreneurs for a long time. Indeed, in general, most social enterprises in the Netherlands are rather young. According to ABN AMRO, about $40 \%-50 \%$ are in an early stage of development, another $40 \%-45 \%$ have reached a somehow more advanced stage of development and only 5\%-15\% have successfully left the start-up phase (ABN AMRO 2017: 17). This matches data from McKinsey, which states that 


\section{Karré}

(...) the average state of growth of social enterprises is low. About half of our survey respondents said they were in the early-stage growth phase [i.e. between 2 and 5 years old] and 20\% in seed [0-2 years] or start-up [1-3 years] phases. That means that only about $30 \%$ are in later stages of growth.

Keizer et al. (2016: 6)

This is also the picture that arises from the Social Enterprise Monitor. Of the 210 social enterprises that provided information for this study, $16 \%$ had been established in or after 2017, 48\% between 2012 and 2016 and $16 \%$ between 2007 and 2011. Older social enterprises are rare: $8 \%$ of those that participated in the study had been established between 2002 and 2006, 6\% between 1995 and 2001 and only 5\% had been established in or before 1995 .

\section{Financial Results}

Information about the turnover and profits of the social enterprises in the ABN AMRO Social Impact Fund database also supports the picture that most social enterprises in the Netherlands are fairly young and in an early stage of development (ABN AMRO 2017: 19). About $80 \%$ have less than $€ 1.5$ million in turnover and $58 \%$, less than $€ 500,000$. There are also social enterprises that generate more than $€ 5$ million in turnover, but these only represent some $4 \%$ of the sample (about 160 to 200 enterprises); they are the biggest social enterprises, such as ethical chocolate maker Tony's Chocolonely, smartphone producer Fairphone and biological supermarket Beebox/Willem\&Drees. Most social enterprises only have a comparatively modest turnover, which is mostly due to the fact that most social enterprises are established to tackle concrete social problems in a certain area and with a limited target group (ABN AMRO 2017: 19). In general, the financial performance of social enterprises in the Netherlands falls behind that of for-profit enterprises. "Fewer than one in three social enterprises is profitable", McKinsey notes (Keizer et al. 2016: 13). According to ABN AMRO (2017: 21), 44\% of the social enterprises they surveyed did not (yet) turn a profit and $36 \%$ just broke even.

Data from the Social Enterprise Monitor show a somewhat different picture (Social Enterprise NL 2019: 13). Here 42\% of social enterprises reported to have made a profit and another $22 \%$ stated that they had broken even. Only $36 \%$ reported that they were losing money. Of course, a simple explanation for the fact that social enterprises having taken part in the Social Enterprise Monitor survey seem to fare better, from the point of view of financial results, than their counterparts analysed by ABN AMRO and McKinsey may be that profitable organisations have more spare time to complete surveys. 


\section{Impact}

Social enterprises find it difficult to measure the impact of their activities. "Barely half of social enterprises measure some form of impact, and 35\% [only] measure a relevant unit, such as $\mathrm{CO}_{2}$ emissions. The other half do not yet measure their social impact" (Keizer et al. 2016: 11). Social enterprises that do not measure their impact declare that this is due to the fact that they lack a good method to measure impact or that they do not have sufficient financial resources-a point also made in the recent survey conducted by the Social and Economic Council of the Netherlands, an independent advisory body (Sociaal-Economische Raad 2015). Because of these difficulties, we do not yet know much about whether social enterprises really make a difference and how we should value the many claims made by social entrepreneurs.

There are initiatives to create insights into the impact of social enterprises, such as the "Impact Path" tool (Het Impactpad), developed by Erasmus University Rotterdam. Until such tools become widely used, the lack of data on the real impact of social enterprises will remain a problem and undermine these initiatives' credibility:

In a segment where adding social value is the single differentiating factor, impact measurement is the currency of the sector's value. Lacking standards for impact measurement, the absence of an impact measurement infrastructure, and high measurement costs for individual enterprises create obstacles for social enterprises individually and for the sector as a whole.

Keizer et al. (2016: 11)

\subsubsection{Synthetic Analysis}

Despite the differences between the three reports, several conclusions can be drawn concerning the different SE models in the Netherlands. How many social enterprises exist in the country is a bone of contention; the lack of a common definition makes analyses and comparisons tricky, and estimates about the number of social enterprises vary widely (from a few hundreds to about 6,000). Some elements about Dutch social enterprises can nevertheless be highlighted: Most social enterprises seem to be small- or mediumsized businesses that have come into being only fairly recently. Most of them provide health and welfare services, and work integration is the most common main social mission. The majority of social enterprises, according to both the report by McKinsey and the Social Enterprise Monitor, have the legal form of private-limited company; the second most common legal form is that of foundation, followed by cooperatives and sole-proprietor businesses. Impact measurement currently remains a challenge. 


\section{Karré}

Based on the information available on the legal forms of social enterprises, an analysis can be made of how they fit the typology put forward by Defourny and Nyssens (2017). These authors describe four major SE models:

- the social-cooperative (SC) model, which is rooted in the third sector, but differs from traditional mutual-interest organisations (cooperatives and associations) in that the enterprises belonging to this model combine the pursuit of the mutual interest of their members with an objective of general interest, benefiting the community at large;

- the social-business (SB) model, which originates in the market place but strives to integrate and combine economic and social purposes;

- the entrepreneurial non-profit (ENP) model, which includes all nonprofit organisations, most often general-interest associations, that use earned-income strategies to support their social mission;

- the public-sector social enterprise (PSE) model, which originates in the public sector and embraces all public-sector spin-offs.

Using these four models as a lens to look at the data from the three reports, at first glance we might conclude that most Dutch social enterprises are closest to the social-business model: they are organisations operating under the legal form of a private limited company that try to achieve a social mission by engaging in commercial activities.

However, as discussed in section 1, in the Netherlands, the SE sector is generally seen as clearly distinct from the traditional non-profit sector, which, in the Netherlands, has a long history, with many organisations established long before the SE label was invented. This limitation is clearly evidenced by the definition used by Social Enterprise NL, which explicitly excludes organisations that derive more than half of their income from donations and subsidies, and all three cited reports use a similar definition. If we, instead of using the conventional Dutch idea of what a social enterprise is, look at the situation in the Netherlands using the much wider approach put forward by Defourny and Nyssens, the number of social enterprises rises dramatically. Indeed, while traditional non-profits are excluded using the Dutch definition of social enterprise, most of them match the definition of "entrepreneurial non-profits" as described by these authors. If we include this type of social enterprise, they make up the largest group by far. Many large institutions, such as universities and hospitals, would be included in this category, dwarfing the other types of social enterprise.

\subsection{Social Enterprises' Relations with Public Authorities}

The government, at both national and local levels, is the main institution that shapes the profile of social enterprises in the Netherlands. 
As explained before, there is no specific legal form for social enterprises in the Netherlands yet, though in July 2020 the national government announced its plans to establish by law what it calls the "social limited-liability company" (maatschappelijke BV, or BVm). Many social entrepreneurs support this initiative, as they hope that this will help them to gain better recognition in society and develop their business. By opting for the introduction of a specific legal form, the government decided to disregard the advice from a joint OECD/EU report it had commissioned. In this report, the OECD and EU indeed advised against such legal evolution on several grounds, recommending that the Netherlands instead adopt an official and operational definition, leading to a registration process either by public authorities or by private stakeholders (OECD/EU 2019).

Relationships with local governments are even more important, for individual social enterprises, than those with the national government. Indeed, discussion about the relationship between public authorities and social enterprises mainly takes place at the local level, as municipalities play a prominent role in the provision of public health and welfare services in the Netherlands. Moreover, most social enterprises are only active at the local level. So far, only about $40 \%$ of local governments have devised specific policies for social enterprises (PwC 2018: 10), but the four largest municipalities in the country (namely Amsterdam, Rotterdam, Utrecht and The Hague) have developed action programmes or action plans on social entrepreneurship ("Actieprogramma Sociaal Ondernemerschap" or "Actieplan Sociaal Ondernemen") (Keizer et al. 2016: 7). These action plans aim to create an ecosystem wherein social enterprises can thrive, but they also make it clear that these initiatives should not expect preferential treatment.

According to the Social Enterprise Monitor, relationships with the local government are cited as the main challenge by Dutch social enterprises striving to achieve a greater impact; this issue is even seen as a bigger obstacle than traditional entrepreneurial challenges, such as attracting funding and extending the customer base (Social Enterprise NL 2019: 11). This is mainly due to the hybrid character of social enterprises (Karré 2018).

A study conducted by the Social and Economic Council of the Netherlands (SER) in 2015 found that many of the social entrepreneurs surveyed felt that they were not adequately recognised by the government and by society at large for what they did, due to the confusion surrounding the term social enterprise (Sociaal-Economische Raad 2015). They also felt themselves thwarted by rules and regulations, which, in their eyes, were ill adapted to the innovative approaches they implemented; European procurement rules, for example, made it difficult for local authorities to grant contracts to social enterprises. The relationship between social enterprises and local governments is also made 


\section{Karré}

complicated by the challenges that social entrepreneurs experience when attempting to measure the impact of their work. Social enterprises are often too small to apply elaborate tools for social-impact assessment; moreover, they often reject them for ideological reasons-for example, because such tools often measure output rather than outcome. The SER recommended that the government improve the financial climate, invest in impact measurement and increase awareness about social enterprises among civil servants.

There are four main challenges in the relationship between social enterprises and municipalities (Karré and Van Meerkerk 2019):

- Awareness and recognition: most municipalities are unfamiliar with the SE phenomenon. They do not know yet how to recognise these initiatives and how to deal with them. Because of this, SE initiatives are often not seen yet as viable alternatives for working together with non-profits or commercial enterprises.

- Funding and procurement: many municipalities are used to funding activities in the sectors in which social enterprises are most active (health and welfare, work integration) by providing subsidies to foundations or associations, but they are not used yet to buying services from a (social) enterprise. Even though Dutch procurement law gives (local) governments some leeway to do business with social enterprises even if there are cheaper alternatives, municipalities usually choose the cheapest supplier for the goods and services they buy. This puts social enterprises at a disadvantage, as they are often more expensive than "regular" companies, because they also pursue social goals, in addition to their commercial goals.

- Difficulties in matching policies with practices of social enterprises: social enterprises and their activities are often innovative; for examples, they work in an "integrative" manner, crossing the boundaries of government "silos" and policy domains. But, government regulation and financial streams are often not yet organised in that way. Because of this, regulations often thwart the plans of social enterprises, for example, when policies from different domains contradict one another.

- Accountability and impact measurement: Because of their hybrid character, at the interface of the state, the market and society, social enterprises find it more difficult than "normal" companies to demonstrate their accountability. Social enterprises have different and often contradictory goals, and measuring their impact is often complex and expensive. This poses a problem for municipalities willing to make use of their services, as accountability requirements linked to the spending of public funds demand more hard and structured information than many social enterprises can provide. 
In summary, what it comes down to is that in practice, municipalities and social enterprises have different and often contradictory institutional logics. They do not speak the same language, have different cultures and different ways of doing things. Social enterprises often do not understand how government and politics work, and the opposite is also true.

\section{Conclusion}

In the Netherlands, there is increased interest in social enterprises but also a lot of confusion about the term. In order to finally end this discussion, in July 2020, the national government announced its intention to introduce a new legal form and framework for social enterprises. So far, little is known about the new law, and with new elections planned in early 2021, which could lead to a new coalition, with new priorities, there is no guarantee that this law will indeed ever be introduced. Another reason for the prevailing confusion is that, due to the country's history of public-service provision by hybrid organisations, the list of organisations that could be labelled as social enterprises is extensive. In order to distinguish social enterprises from so-called traditional nonprofits, social enterprises are often defined as organisations that generate more than half of their income on the marketplace, but such distinction is largely arbitrary. We will have to wait for a first draft of the new law and the discussions surrounding it to establish its chances to ever really coming into effect. In the meantime, the confusion and ambiguity surrounding social enterprise in the Netherlands is likely to continue.

\section{Notes}

1 See http://ec.europa.eu/growth/sectors/social-economy/enterprises_en.

2 See https://www.social-enterprise.nl/english.

3 This charitable foundation was established in 2012 by Willemijn Verloop, founder of the non-governmental organisation War Child Holland, and Mark Hillen, a former management consultant. All social enterprises that meet the European definition and that derive at least $50 \%$ of their income from trade or other forms of value exchange, excluding donations or subsidies, can become members. In 2019, Social Enterprise NL had 345 members and membership fees varied between $€ 295$ and $€ 1,195$ per year.

4 See https://www.social-enterprise.nl/english.

5 For a more elaborate description, see Karré (2011), section 1.2, on which the present section is based.

6 Based on data provided by CBS Statistics Netherlands, the Dutch Chamber of Commerce and McKinsey's own Social Enterprise Survey.

\section{References}

ABN AMRO (2017) De noodzaak van marktontwikkeling voor sociale ondernemingen. De romantiek voorbij, Amsterdam: ABN AMRO. 


\section{Karré}

Andeweg, R. \& Irwin, G. A. (1993) Dutch Government and Politics, Houndmills Basingstoke: Macmillan.

Brabander, R. de Emmerik, R. \& Peters, D. (2009) Een waardevolle spagaat: een verkenning van sociaal ondernemerschap, Antwerpen \& Apeldoorn: Garant.

Brandsen, T., Cattacin, S., Evers, A. \& Zimmer, A. (2016) Social innovations in the urban context, Heidelberg: Springer Verlag GmbH u. Co.

Defourny, J. \& Nyssens, M. (2017) “Mapping social enterprise models: Some evidence from the 'ICSEM' Project”, Social Enterprise Journal, Vol. 13, No. 4, pp. 318-328.

Head, B. W. \& Alford, J. (2015) “Wicked problems implications for public policy and management", Administration \& Society, Vol. 47, No. 6, pp. 711-739. Available HTTP: https://doi.org/10.1177/0095399713481601.

Hogenstijn, M., Meerman, M., \& Zinsmeister, J. (2018) “Developing stereotypes to facilitate dialogue between social entrepreneurs and local government", Journal of Innovation and Entrepreneurship, Vol. 7, No. 1, p. 3. Available HTTP: https://doi.org/10.1186/s13731-018-0084-5.

Karré, P. M. (2011) Heads and Tails: Both Sides of the Coin: An Analysis of Hybrid Organizations in the Dutch Waste Management Sector, The Hague: Eleven International Publishing.

Karré, P. M. (2018) "Navigating between opportunities and risks: The effects of hybridity for social enterprises engaged in social innovation", The Journal of Entrepreneurial and Organizational Diversity, Vol. 7, No. 1, pp. 37-60. Available HTTP: https://doi.org/10.5947/jeod.2018.003.

Karré, P. M. \& Van Meerkerk, I. (2019) Samen werken aan de wijk. Een bestuurskundige reflectie op de relatie tussen wijkcoöperaties en gemeente in Rotterdam, Rotterdam: Kenniswerkplaats Leefbare Wijken.

Keizer, A., Stikkers, A., Heijmans, H., Carsouw, R. \& Van Aanholt, W. (2016) Scaling the Impact of the Social Enterprise Sector, Amsterdam: McKinsey.

Lijphart, A. (1975) The Politics of Accommodation: Pluralism and Democracy in the Netherlands (2d ed., rev.), Berkeley: University of California Press.

OECD/EU (2019) "Boosting social entrepreneurship and social enterprise development in the Netherlands. In-depth policy review", OECD LEED Working Papers, Paris: OECD Publishing.

Pape, U. \& Brandsen, T. (2016) The Third Sector in The Netherlands-Third Sector Impact Project Policy Brief No. 8/2016 [Policy Brief], Nijmegen: Third Sector Impact Project.

PwC (2018) Prille kansen: de samenwerking tussen sociale ondernemingen en gemeenten in Nederland, Amsterdam: PwC.

Rittel, H. W. J. \& Webber, M. M. (1973) "Dilemmas in a general theory of planning”, Policy Sciences, Vol. 4, No. 2, pp. 155-169. Available HTTP: https://doi.org/10.1007/BF01405730.

Schulz, J. M., Steen, M. van der, \& Twist, M. van (2013) De koopman als dominee: sociaal ondernemerschap in het publieke domein, Den Haag: Boom Lemma uitgevers.

Sociaal-Economische Raad (2015) Sociale ondernemingen: een verkennend advies, Den Haag: Sociaal-Economische Raad (SER).

Social Enterprise NL (2019) De Social Enterprise Monitor 2019, Amsterdam: Social Enterprise NL. 
Sterk, E., Specht, M., Walraven, G. \& Zweerts de Jong, S. (2013) Sociaal ondernemerschap in de participatiesamenleving: van de brave naar de eigenwijze burger, Antwerpen \& Apeldoorn: Garant.

van Thiel, S. (2000) Quangocratization: Trends, Causes and Consequences, Amsterdam: Interuniversity Center for Social Science Theory and Methodology. 